\title{
Environmental Monitoring in the Mechara caves, Southeastern Ethiopia: Implications for Speleothem Palaeoclimate Studies
}

\author{
Asfawossen Asrat ${ }^{1}$, Andy Baker ${ }^{2}$, Melanie J. Leng ${ }^{3,4}$, John Gunn ${ }^{2}$, Mohammed Umer
}

\begin{abstract}
:
Asrat A., BakerA., Leng M.J., Gunn J. and Umer M. 2008. Environmental Monitoring in the Mechara caves, Southeastern Ethiopia: Implications for Speleothem Palaeoclimate Studies. International Journal of Speleology, 37 (3), 207-220. Bologna (Italy). ISSN 0392-6672.

The interpretation of palaeoclimate records in speleothems depends on the understanding of the modern climate of the region, the geology, the hydrology above the caves, and the within-cave climate. Monitoring within-cave climate variability, geochemistry of speleothem-forming drip waters, and associated surface and groundwater, provides a modern baseline for interpretation of speleothem palaeohydrological and palaeoclimate records. Here, we present results of such monitoring of the Mechara caves in southeastern Ethiopia, conducted between 2004 and 2007. Results show nearly constant within-cave climate (temperature and humidity) in all caves, which generally reflects the surface climate. Groundwater and surface water geochemistry is similar across the region (except slight modification by local lithological variations) and modern drip water isotope data fall close to regional Meteoric Water Line, but speleothems further from equilibrium. Holocene and modern speleothems from these caves give high-resolution climate records, implying that the Mechara caves provide a suitable setting for the deposition of annually laminated speleothems that could record surface climate variability in a region where rainfall is sensitive to both the strength of the intertropical convergence zone as well as Indian Monsoon variability.
\end{abstract}

Keywords: Mechara, Ethiopia, cave monitoring, cave climate, drip water geochemistry, palaeoclimate.

Received 27 August 2008; Revised 1 October 2008; accepted 2 October 2008

\section{INTRODUCTION}

Extensive limestone beds with great potential for caving are exposed in three regions in Ethiopia: the Mekelle Outlier in the North (Tigray), the Blue Nile Basin in central Ethiopia, and the Ogaden Basin (including Western Harrarghe region where the Mechara karst system is located) in the Southeast (Figure 1). The Mechara karst system, discovered in 1995-96 (Brown et al., 1998), is located in the Southeastern Ethiopian plateau and lies at the foot of a long mountain ridge formed by Oligocene flood basalts (Figures 2A and $3)$. The ridge marks the southeastern margin of the NE-SW trending Main Ethiopian Rift. The steep ridge rising to an altitude of more than $3000 \mathrm{~m}$ a.s.1. unconformably overlies Mesozoic sedimentary successions. The latter form an undulating plateau at

1 Department of Earth Sciences, Addis Ababa University, P.O.

Box 1176, Addis Ababa, Ethiopia; e-mail: asrata@geol.aau.edu.et 2 School of Geography, Earth \& Environmental Sciences, The University of Birmingham, Birmingham B15 2TT, UK; e-mail: a.baker.2@bham.ac.uk

3 NERC Isotope Geosciences Laboratory, British Geological

Survey, Keyworth, Nottingham NG12 5GG, UK

4 School of Geography, University of Nottingham, Nottingham NG7 2RD, UK an average elevation of $1600 \mathrm{~m}$ a.s.1., which extends from the foot of the basalt ridge towards the east and southeast. The Mechara karst system developed on Jurassic limestone beds, regionally known as the Antalo Limestone Unit (Bosellini et al., 1997; Asrat, 2002), and locally subdivided into the Hammanlei Formation, Uarandab series and Gabredare series (Assefa, 1988; Bosellini et al., 1997). All the caves in the Mechara karst system have been developed on the Gabredare series. The limestone unit, with a total thickness of 500-800 m, consists of thin, fossiliferous limestone beds intercalated with marl and sandy limestone beds at the top (upper Gebredare series), and massive, crystalline limestone beds intercalated with thin marl and mudstone beds at the bottom (lower Gabredare series). The Antalo Limestone unit is conformably overlain by Jurassic shale (Agula Shale unit) with an estimated thickness of $150 \mathrm{~m}$, which comprises variegated shale, marl and mudstone intercalated with thin beds of crystalline limestone and, rarely, dolomite. Cretaceous sandstone (Ambaradam Formation) conformably overlies the Agula Shale. The Ambaradam Formation, with a total thickness of about $300 \mathrm{~m}$ in the Mechara area, consists of white to pink, medium to coarse-grained, immature, clastic sandstone beds intercalated with silt, shale, 


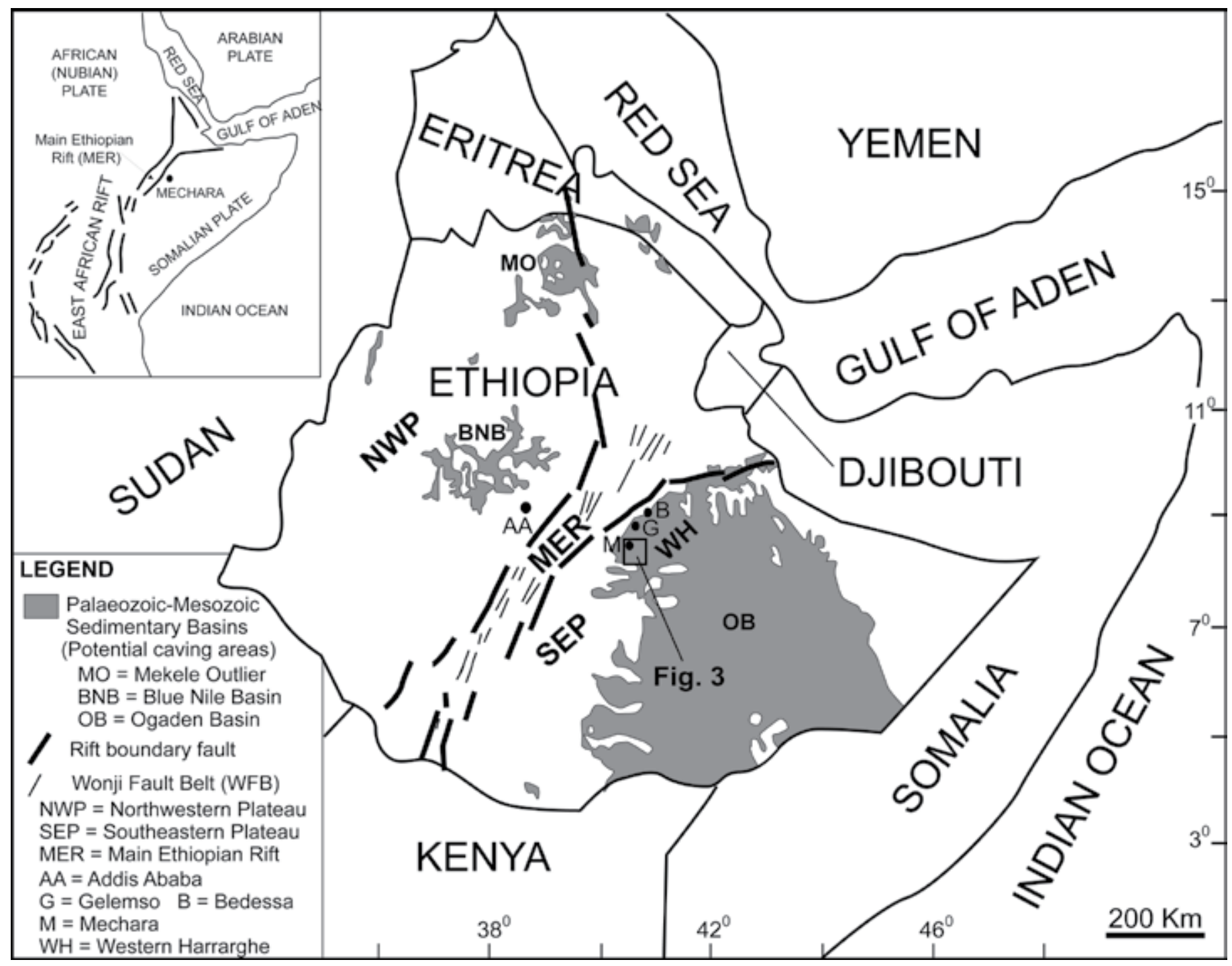

Fig. 1. Regional geological and structural setting of Ethiopia showing major limestone terrains. Inset shows the regional structural setting of Northeast Africa. Location of figure 3 is marked.

mudstone, laterite beds and quartz conglomerates. The Ambaradam Formation is exposed in isolated hills/ridges, which form the higher reaches of the undulating plateau.

The Mesozoic succession is affected by fractures and normal faults with general NE-SW orientation parallel to the rift margin. These fractures are thought to be related to the major rifting episode that formed the great East African Rift system as their magnitude and frequency decrease in the southeast direction away from the rift margin. The Mechara cave system developed along major NE-SW aligned rift passages, parallel to the general orientation of the Main Ethiopian Rift, suggesting karstification triggered by rift-related extensional tectonics. The area is still seismically active (Gouin, 1979; Ayele and Kulhánek, 2000).

The Mechara karst system has been studied since 2003 resulting in the discovery of many cave entrances and chambers (Baker et al., 2005, Ruggieri, 2006). Speleothems recovered from three caves (Achere, Rukiessa and Bero) gave high-resolution, multi-proxy palaeohydrological and palaeoclimatic signals (Asrat et al., 2007; Baker et al., 2007, 2008; Blyth et al., 2007). Here we present descriptions of the three major cave systems we have studied (Achere-Aynage, Rukiessa and Bero) as well as results of monitoring of caves climate, and surface and groundwater geochemistry since 2004 . This monitoring data will form the baseline for further speleothem palaeoclimate studies in the region.

\section{MECHARA CAVE SYSTEMS}

Sixteen cave entrances have been identified, some of which lead to extensive cave systems (>100m), whilst others have only been explored for some tens of meters. Here we describe three of the seven major cave systems (Figure 3): Achere-Aynage, Rukiessa, and Bero. These caves are easily accessible and, most importantly, contain both relict and actively growing and dripping speleothems suitable for monitoring and palaeoclimate studies.

\section{Achere-Aynage}

The Achere-Aynage cave system comprises $7.1 \mathrm{~km}$ of surveyed passage and is the second-longest cave system in Ethiopia (Brown et al., 1998; Gunn \& Brown, 1998). This system is made up of two caves, developed along numerous parallel rifts generally oriented along a NE-SW direction. The main entrance to Achere cave (37 651075E, $0951801 \mathrm{~N}$, elevation: $1534 \mathrm{~m}$ a.s.1.) is 

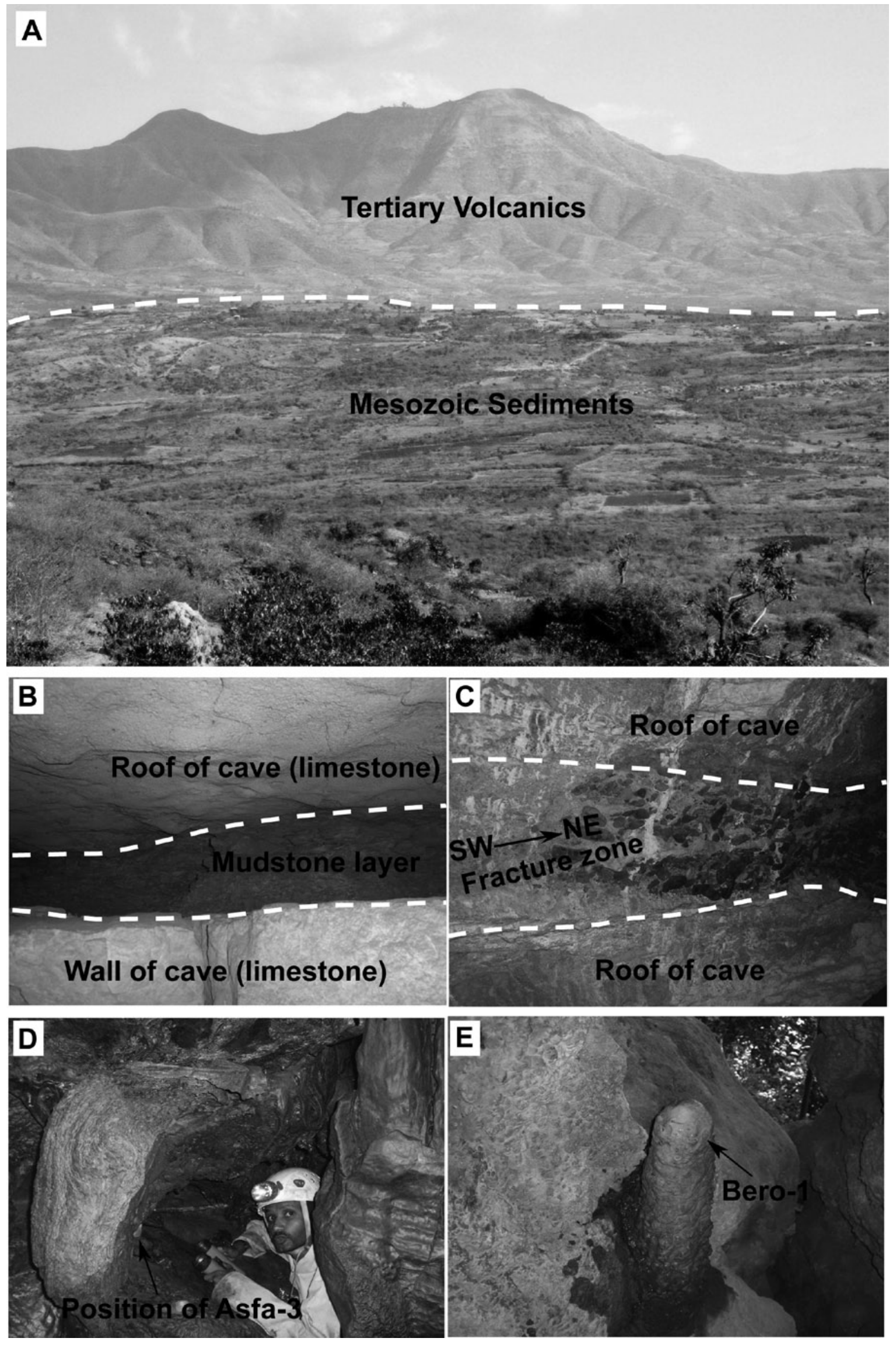

Fig. 2. Some landscape and cave features from Mechara: (A) the landscape of Mechara; the Tertiary volcanics (mostly Oligocene basalts) form part of the Southeastern Ethiopian highlands while the Mesozoic sediments (Sandstones underlain by the cave forming limestones) form the low-lying undulating plain; (B) A mudstone layer marks the roof of the Achere cave; (C) Calcified basaltic conglomerates deposited along NE-SW fracture in the Achere cave; (D) Asfa chamber in the Rukiessa cave; the position of the drip depositing Asfa-3 stalagmite is indicated; and (E) Bero-1 stalagmite before it is removed from a small chamber close to the main Bero cave. 


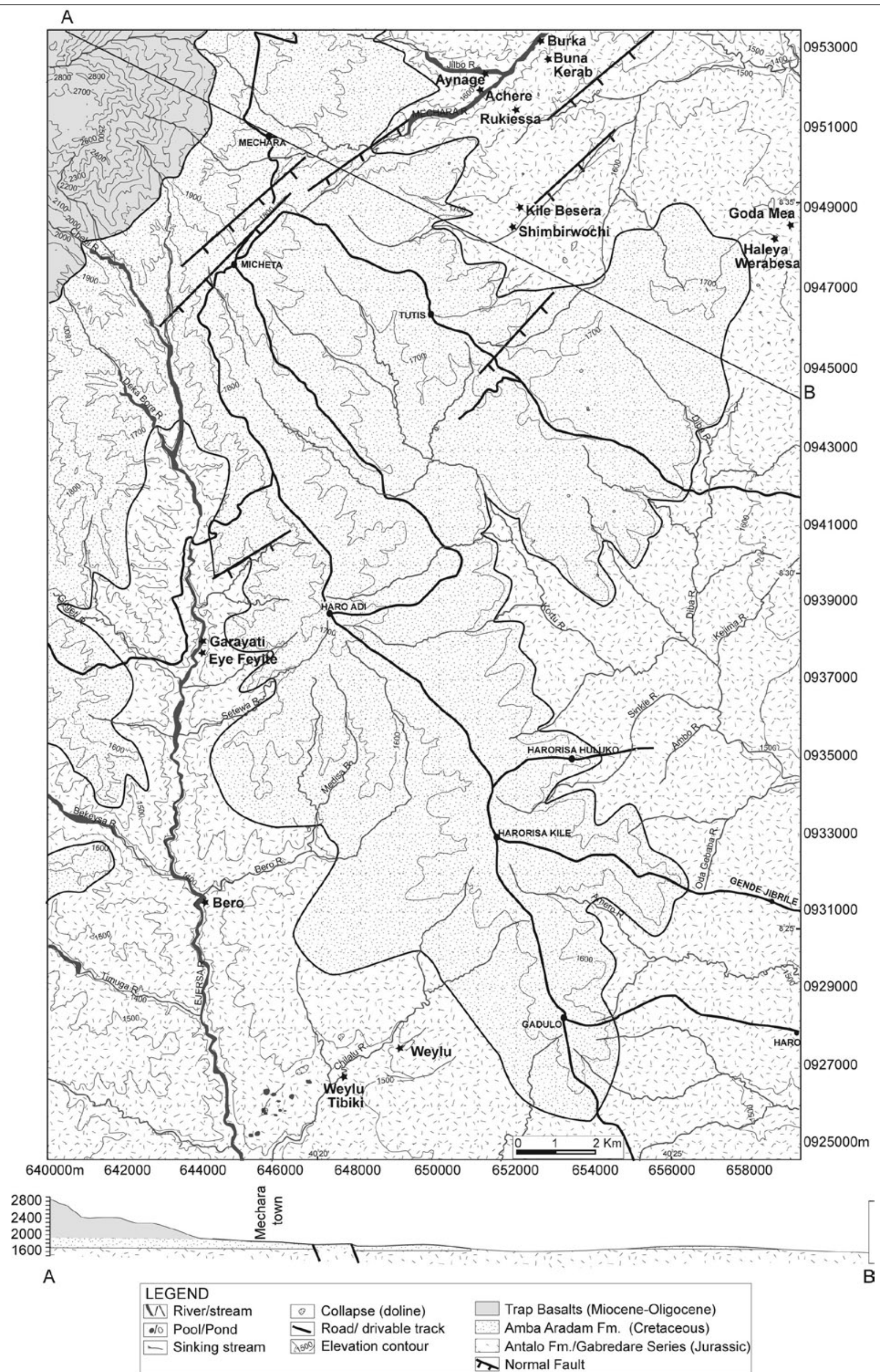

Fig. 3. The Mechara karst area: topography, geology, structure and surface drainage system. A geological cross-section along line A-B shows thin sandstone layer overlying the cave forming limestone terrain. Locations of caves are marked. 
located at the top of a low cliff forming the western bank of the Mechara River and the main entrance to Aynage cave (37 651100E, 09 52366N, elevation: 1550 $\mathrm{m}$ a.s.1.) is located north of Achere, forming the south bank of the Jilbo River. A total of $3830 \mathrm{~m}$ of passage has been surveyed in Achere and $3300 \mathrm{~m}$ in Aynage (Figure 4A). At their closest point the two caves are only $30 \mathrm{~m}$ apart and although a physical connection has not been made they are clearly part of the same maze cave network. All accessible passage lies within a 20-25 m vertical zone in the upper part of the Antalo Limestone parallel to bedding. The roof is a mudstone/ marl horizon within the limestone unit (Figure 2B) which has a fairly constant elevation but the bedrock floor is nowhere exposed, being covered by fine dust composed largely of skeletal moth remains with some bat guano. Other sediments present comprise red sands and mud with rare small reworked basalt cobbles; loose yellow sands with some reworked wellrounded basalt cobbles and calcite cemented basalt conglomerates and agglomerates. These have been deposited by invading surface streams during flooding episodes. Conduit inception was probably facilitated by fracturing related to the rift tectonics (Figure 2C), while lithology might have restricted the zone of conduit development. Currently the Achere-Aynage cave system is relict, perched some $10 \mathrm{~m}$ above the active stream. However, a very small amount of sodastraw speleothem formation occurs, associated with the thin mudstone/marl layer at the roof, which seems to focus groundwater flow (Baker et al., 2005; Asrat et al., 2007). Further evidence that the cave system has been repeatedly reactivated by surface water inflow is provided by relict and re-dissolved speleothems (Gunn \& Brown, 1998), whilst collapse features were probably triggered by tectonic activity.

The Achere-Aynage cave system contains abundant relict speleothems twelve of which were sampled (four from Achere and eight from Aynage). The basal ages of six of these stalagmites range from 69,000 to 900 years BP (U-Th method; unpublished data) and they show visible annual lamination, making them suitable for high-resolution palaeoclimate studies of the Late Quaternary (Asrat et al., 2007).

\section{Rukiessa}

This system comprises the Rukiessa cave whose entrance is located in a low hill about $1 \mathrm{~km}$ east of the eastern bank of the Mechara river (37 651550E, $0951300 \mathrm{~N}$, elevation: $1618 \mathrm{~m}$ a.s.1.), and the Burka spring which emerges from a horizontal cavity in the limestone cliff forming the eastern bank of the Mechara river (37 652300E, $0953010 \mathrm{~N}$, elevation $1515 \mathrm{~m})$. In between these two entrances is located a vertical sink (Buna Kerab cave; 37 652746E, $0952897 \mathrm{~N}$, elevation $1618 \mathrm{~m}$ ) some $500 \mathrm{~m}$ to the SSE of the Burka spring. Though the connection of these three caves has not yet been proven, the hydrogeologic and topographic nature of the area suggests that they are probably part of the same extensive system, and that the Burka spring is the point of emergence of the underground stream that drains the Rukiessa cave.

The Rukiessa cave entrance is at the bottom of a linear depression. The cave contains approximately $1.1 \mathrm{~km}$ of surveyed passage (Ruggieri, 2006) and may be characterized as a vertical passageway formed along vertical fractures truncated by horizontal "chambers" formed following bedding planes (Figure 4B). The cave is wet, regularly flushed by seasonal floods, and contains allogenic sediments, especially in the entrance chamber. The entrance is a $2 \mathrm{~m}$ deep vertical hole in the sandy limestone layer leading to a $6 \mathrm{~m} \times 6 \mathrm{~m}$ chamber up to $15 \mathrm{~m}$ in height which has irregular floor and roof morphology. A tight, vertical rift leads to the Mercury chamber $(3 \mathrm{~m} \times 3 \mathrm{~m} \times 1 \mathrm{~m}$ high) which is directly beneath the entrance chamber, at $\sim 25$ $\mathrm{m}$ below the surface. The roof of this chamber is decorated by active stalactites, which feed some active (modern) stalagmites including Merc-1, which returned a high-resolution palaeoclimate record of the last hundred years (Baker et al., 2005, 2007). At the eastern end of Mercury Chamber there is another chamber which is partly filled by large limestone blocks that have fallen from the roof and walls. A climb down from this chamber leads to Asfa Chamber, the third level from the surface at an approximate depth of $30 \mathrm{~m}$. Asfa chamber is very wet, with pool waters fed by drips from active stalactites, and percolation fed-streams (Figure 2D). Several active and non-corroded stalagmites including Asfa-3 (Baker et al., 2007), and older ones including Asfa-4, Asfa-5 and Asfa- 6 are present in this chamber. At its western end, this chamber gives way to a $\sim 10 \mathrm{~m}$ deep vertical shaft.

The Burka spring gushes out in the form of a small cascade $5 \mathrm{~m}$ from the level of the Mechara River. Although the stream course is not clear from the entrance, a very tight and long fracture leads to the groundwater feeding system. This narrow conduit runs uphill for about $80 \mathrm{~m}$ before it gives way to a small mud-flooded gallery. The Buna Kerab cave is in a steep-sided depression that is assumed to be connected with the conduits that feed the Burka spring. The depression formed along a NESW oriented fracture zone, which at the surface forms an uneven structural depression of average $2 \mathrm{~m}$ depth along the same direction. The depression gives way to a $20 \mathrm{~m}$ deep shaft extended along the same structural direction.

\section{Bero}

The Bero cave system (37 643926E, 09 31425N, elevation: $1363 \mathrm{~m}$ a.s.l) comprises a series of dry, relict, well decorated rift passages with a total length of $\sim 300 \mathrm{~m}$, at different elevations in a cliff that has been intersected by a surface river valley (the Ejersa River). The morphology of the passages is largely similar to the Achere-Aynage system. There are many relict stalagmites on the floors and walls of the passages. Bero-1 stalagmite (Figure 2E), collected from a small cave entrance formed into a higher cliff at the side of the bigger cave, was deposited over the early to 

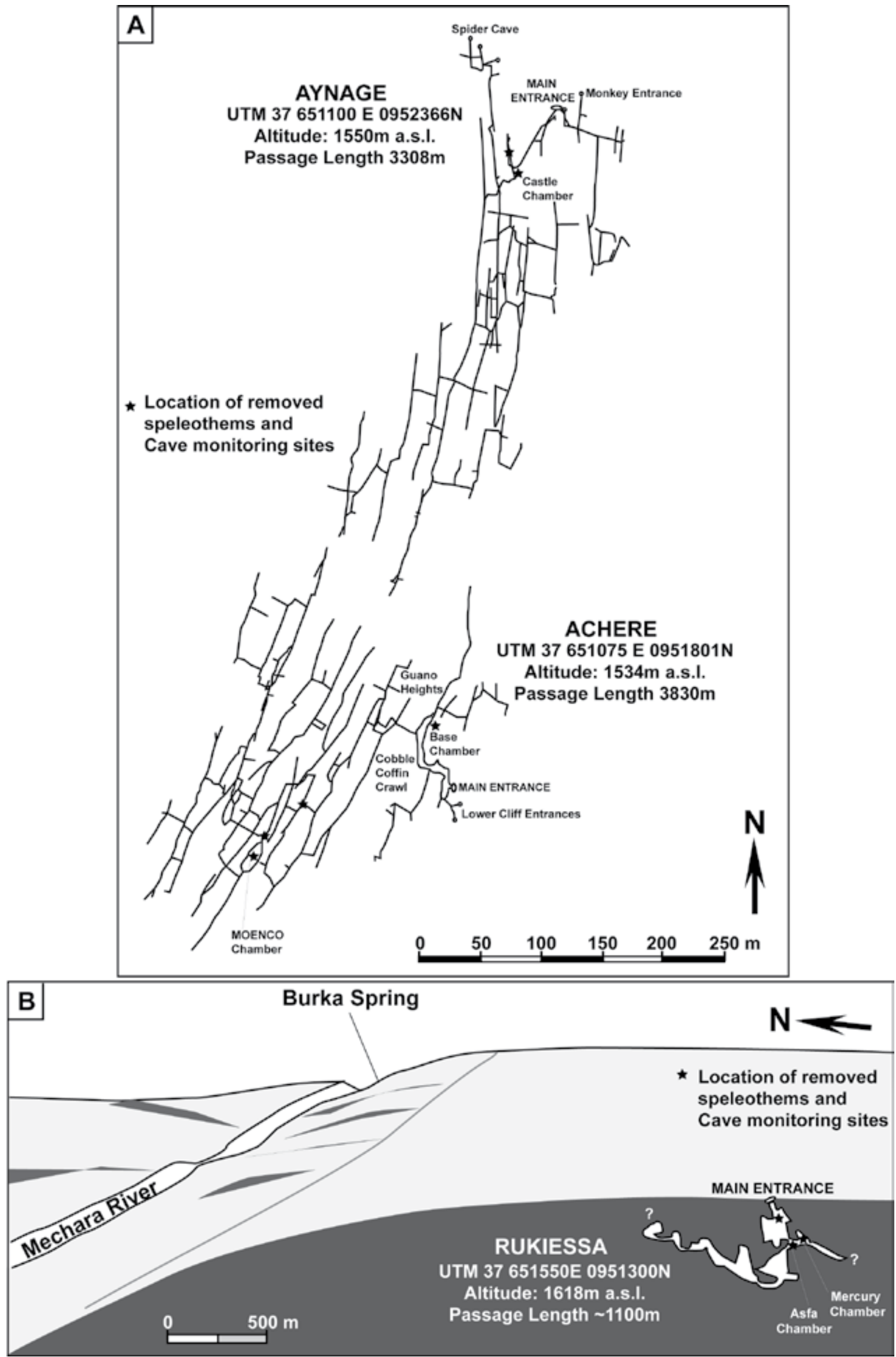

Fig. 4. (A) Cave surveys of Achere-Aynage cave system (modified from Brown et al., 1998); and (B) cross-sectional sketch of the Rukiessa cave; locations of the Mechara river and the Burka spring are marked modified from Ruggieri, 2006. 
middle Holocene and returned a high-resolution palaeoclimate record (Baker et al., 2008).

\section{CLIMATE, HYDROLOGY AND ENVIRONMENT OF THE MECHARA REGION}

The variability in the movement of the InterTropical Convergence Zone (ITCZ) causes most of the interannual variability in rainfall over Ethiopia (Seleshi \& Zanke, 2004), with the dynamics of the ITCZ known to be teleconnected to El Niño (Nicholson, 2000), most likely via changes in Indian Ocean Sea Surface Temperature. The climate of the Southeastern Ethiopian plateau is particularly governed by the general pattern of winds and pressure over the African continent, strongly modulated by topography and the proximity of the Indian Ocean. The region is subject to the seasonal migration of the ITCZ and is very sensitive to monsoon variability, almost all the rainfall being ultimately derived from the Indian and Atlantic Oceans (Griffiths, 1972).

Locally, the Mechara area, at an altitude of 1500$1800 \mathrm{~m}$ a.s.1., is characterized by an average annual temperature of $21^{\circ} \mathrm{C}$ and mean annual rainfall of $\sim 1000 \mathrm{~mm}$. Temperature is generally constant, while precipitation is bimodal and shows strong seasonal variation where the main rainy season extends from July to September ('big rains') and the 'little rains' fall between March and May. The main rainy season occurs when the northward movement of the ITCZ dominates the airflow. This in itself produces rain, but rainfall is also generated by the development and persistence of Arabian and Sudan thermal lows at $20^{\circ} \mathrm{N}$ latitude, the development of the tropical easterly jet and its persistence, and the generation of the low-level 'Somali jet' that enhances low level southwesterly flow (Seleshi \& Zanke, 2004; Baker et al., 2007). The spring rainy season coincides with the southward migration of the ITCZ and the associated movement of the Arabian high towards the north Arabian Sea, allowing the development of a thermal low over the south of Sudan, with moist easterly winds drawn towards this low producing the spring rains in Ethiopia.

The Mechara area is drained by three rivers that originate on the basalt mountain ridge and drain towards the Ogaden lowlands (Figure 3): the Ejersa, Mechara and Kortu rivers flow to the south, east and southeast, respectively. Most cave systems in the area are truncated and modern rivers expose their entrances, while others are accessed through the mouth of sinking streams.

Three soil classes underlie the Mechara area. Relatively thick, fine, black vertic luvisols develop over the basaltic sequence. Chromic cambisols develop over the sandstones and shales, which form low hills above the limestone sequence. These soils are in most parts strongly eroded. However, the limestone terrain in general and the tops of the limestone beds into which most of the caves are formed in particular are overlain by very shallow (generally less than $50 \mathrm{~cm}$ deep) rendzinas (Bruggeman, 1986).

The Mechara karst is currently agricultural. Most of the cave entrances are located in cultivated fields dominated by ploughed fields of mainly maize (Zea mays) and millet (Panicum miliaceum), and perennial cash crops, mainly khat (Catha edulis) and coffee (Caffea sp.). Scattered patches of trees and scrub still exist in the area. These are remnants of an earlier wooded vegetation regime, which was destroyed by one of the major agricultural clearances, which occurred across many regions in Ethiopia in general and in the Mechara area in particular during the 1930s (Machado et al., 1998; Blyth et al., 2007).

\section{CAVE MONITORING}

\section{Methods}

We have been regularly monitoring many of the Mechara caves since our first sampling expedition to the region in April 2004. During visits to the caves in April-May 2004, February and October 2005, June 2006, March and September 2007, we have collected close to 100 surface water, groundwater and rainwater samples, and soda straw stalactites for isotopic and geochemical analysis, measured in situ chemical parameters (conductivity, TDS, and $\mathrm{pH}$ ), cave temperature and humidity (summary of analysis results is given in Table 1), and collected more than 30 relict and actively growing stalagmites. Moreover, cave temperature in some caves has been continuously monitored, to complement the rainfall and temperature data analyzed from three National Meteorological stations at Mechara, Gelemso and Bedessa towns (see Figure 1 for locations). Results of monitoring and analysis provide a modern baseline from which we can understand contemporary processes and contextualize past variability.

Cave climate data has been obtained using Kestrel handheld weather stations during all visits to the caves. Handheld stations were used to record relative humidity at different locations within the cave: results are accurate to $\pm 3 \%$ relative humidity, with an upper measurement limit of $95 \%$. Tiny tag temperature loggers have been left in five caves (Rukiessa, Bero, Achere, Aynage and Goda Mea) and continuous cave temperature measurements have been recorded at 30 minutes interval through time. Loggers have a quoted accuracy of $0.25{ }^{\circ} \mathrm{C}$.

Surface water samples (rivers and springs) and cave water samples (stagnant pools, flowing cave streams and drip waters) were collected in 60 or 30 $\mathrm{ml}$ HDPE bottles. On return from the field, samples were analyzed for $\mathrm{pH}$, electrical conductivity and TDS using a WTW 340i Multimeter or Myron Ultrameter II$6 \mathrm{P}$ with an accuracy of $\pm 0.1 \mathrm{pH}$, and $\pm 0.1 \%$ of reading for electrical conductivity and TDS. Samples for isotope analysis were then immediately transferred to fill an $8 \mathrm{ml}$ HDPE bottle. For isotopic analysis, the waters were equilibrated with $\mathrm{CO}_{2}$ using an Isoprep 18 device for oxygen isotope analysis with mass spectrometry performed on a VG SIRA. For hydrogen isotope analysis, an on-line $\mathrm{Cr}$ reduction method was used with either a EuroPyrOH-3110 system coupled to a Micromass Isoprime mass spectrometer or a GV 
Table 1

\begin{tabular}{|c|c|c|c|c|c|c|c|c|c|}
\hline \multirow{2}{*}{ Cave } & \multirow{2}{*}{$\begin{array}{c}\text { Cave Climate } \\
\text { R.H (\%) }\end{array}$} & \multicolumn{3}{|c|}{ Chemistry } & \multicolumn{3}{|c|}{ Cations (ppm) } & \multicolumn{2}{|c|}{ Isotopes $(\% \circ)$} \\
\hline & & $\mathrm{CO}_{2}(\mathrm{ppm})$ & $\mathrm{EC}(\mu \mathrm{S} / \mathrm{cm})$ & $\mathrm{pH}$ & $\mathrm{Ca}$ & $\mathrm{Mg}$ & $\mathrm{Sr}$ & $\delta^{18} \mathrm{O}$ & $\delta \mathrm{D}$ \\
\hline Achere-Aynage & $\begin{array}{c}87.5 \pm 11.5 \\
(n=14)\end{array}$ & $\begin{array}{c}745 \pm 365 \\
(n=15)\end{array}$ & $\begin{array}{c}1004 \pm 686 \\
(n=17)\end{array}$ & $\begin{array}{c}7.81 \pm 0.34 \\
(n=12)\end{array}$ & $\begin{array}{c}125.0 \pm 75 \\
(n=12)\end{array}$ & $\begin{array}{c}15.9 \pm 13.6 \\
(n=12)\end{array}$ & $\begin{array}{c}0.23 \pm 0.08 \\
(n=4)\end{array}$ & $\begin{array}{c}-1.6 \text { to }-0.46 \\
(n=10)\end{array}$ & $\begin{array}{c}-1.5 \text { to } 7.32 \\
(n=6)\end{array}$ \\
\hline Rukiessa & $\begin{array}{c}91.5 \pm 5.5 \\
(n=9)\end{array}$ & $\begin{array}{c}840 \pm 610 \\
(n=13)\end{array}$ & $\begin{array}{c}642.5 \pm 282.5 \\
(n=14)\end{array}$ & $\begin{array}{c}7.81 \pm 0.43 \\
(n=8)\end{array}$ & $\begin{array}{c}55.8 \pm 36.8 \\
(n=12)\end{array}$ & $\begin{array}{c}43.0 \pm 33 \\
(n=11)\end{array}$ & $\begin{array}{c}0.21 \pm 0.14 \\
(n=9)\end{array}$ & $\begin{array}{c}-2.3 \text { to }-0.3 \\
(n=7)\end{array}$ & $\begin{array}{c}-2.2 \text { to } 13.1 \\
\quad(n=6)\end{array}$ \\
\hline Bero & - & - & - & - & $\begin{array}{c}16.3 \pm 5.7 \\
(n=3)\end{array}$ & $\begin{array}{c}11.02 \pm 4.46 \\
(n=3)\end{array}$ & $\begin{array}{c}0.05 \pm 0.01 \\
(n=3)\end{array}$ & - & - \\
\hline Weylu & $\begin{array}{c}83 \\
(n=1)\end{array}$ & - & $\begin{array}{c}503.5 \pm 121.5 \\
(n=3)\end{array}$ & $\begin{array}{c}8.36 \pm 0.04 \\
(n=3)\end{array}$ & $\begin{array}{c}39.3 \pm 4.2 \\
(n=3)\end{array}$ & $\begin{array}{c}35.95 \pm 15.75 \\
(n=3)\end{array}$ & $\begin{array}{c}0.14 \pm 0.03 \\
(n=3)\end{array}$ & - & $\begin{array}{c}1.46 \text { to } 3.88 \\
(n=3)\end{array}$ \\
\hline Goda Mea & - & Up to 18000 & $\begin{array}{c}650 \\
(n=1)\end{array}$ & $\begin{array}{l}7.68 \\
(n=1)\end{array}$ & $\begin{array}{c}102.5 \pm 26 \\
(n=4)\end{array}$ & $\begin{array}{c}37.4 \pm 27.3 \\
\quad(n=4)\end{array}$ & $\begin{array}{c}0.45 \pm 0.21 \\
(n=4)\end{array}$ & - & $\begin{array}{c}-5.4 \\
(n=1)\end{array}$ \\
\hline All Caves & $\begin{array}{c}87.5 \pm 11.5 \\
(n=24)\end{array}$ & $\begin{array}{c}840 \pm 610 \# \\
(n=28)\end{array}$ & $\begin{array}{c}1004 \pm 686 \\
(n=35)\end{array}$ & $\begin{array}{c}7.89 \pm 0.51 \\
(n=24)\end{array}$ & $\begin{array}{c}105.3 \pm 94.7 \\
(n=34)\end{array}$ & $\begin{array}{c}39.15 \pm 36.85 \\
(n=33)\end{array}$ & $\begin{array}{c}0.35 \pm 0.31 \\
(n=23)\end{array}$ & $\begin{array}{c}-2.3 \text { to }-0.3 \\
(n=17)\end{array}$ & $\begin{array}{c}-2.3 \text { to } 13.1 \\
\quad(n=16)\end{array}$ \\
\hline $\begin{array}{l}\text { Pool waters } \\
\text { (all caves) }^{*}\end{array}$ & & - & $\begin{array}{c}611 \pm 433 \\
(n=13)\end{array}$ & $\begin{array}{c}7.69 \pm 0.39 \\
(n=13)\end{array}$ & $\begin{array}{c}72.65 \pm 48.25 \\
(n=18)\end{array}$ & $\begin{array}{c}34.67 \pm 32.63 \\
(n=18)\end{array}$ & $\begin{array}{c}0.40 \pm 0.35 \\
(n=17)\end{array}$ & $\begin{array}{c}-5.1 \text { to } 1.22 \\
\quad(n=17)\end{array}$ & $\begin{array}{c}-27.1 \text { to } 19 \\
(n=18)\end{array}$ \\
\hline Springs & & - & $\begin{array}{c}545 \pm 98 \\
(n=2)\end{array}$ & $\begin{array}{c}7.52 \pm 0.25 \\
(n=3)\end{array}$ & $\begin{array}{c}76.5 \pm 23.5 \\
(n=3)\end{array}$ & $\begin{array}{c}18.3 \pm 3.3 \\
(n=3)\end{array}$ & $\begin{array}{c}0.22 \pm 0.05 \\
(n=3)\end{array}$ & $\begin{array}{c}-2.0 \text { to }-1.6 \\
(n=3)\end{array}$ & $\begin{array}{c}-3.3 \text { to } 1.2 \\
(n=3)\end{array}$ \\
\hline Rivers & & - & $\begin{array}{c}331 \pm 182 \\
(n=2)\end{array}$ & $\begin{array}{c}7.97 \pm 0.22 \\
(n=2)\end{array}$ & $\begin{array}{c}51.8 \pm 23.9 \\
\quad(n=2)\end{array}$ & $\begin{array}{c}14.6 \pm 5.1 \\
(n=2)\end{array}$ & $\begin{array}{c}0.18 \pm 0.04 \\
(n=2)\end{array}$ & $\begin{array}{c}-1.2 \\
(n=2)\end{array}$ & $\begin{array}{c}-2.7 \text { to } 2.7 \\
(n=3)\end{array}$ \\
\hline Rainwater & & - & $\begin{array}{l}25.3 \\
(n=6)\end{array}$ & $\begin{array}{l}8.42 \\
(n=6)\end{array}$ & - & - & - & - & $\begin{array}{c}-9.4 \text { to } 18.8 \\
(n=6)\end{array}$ \\
\hline
\end{tabular}

* Pool waters from Rukiessa, Garayati, Eyefeyite and Goda Mea caves. \# Excludes measurements from Goda Mea cave.

Instruments Isoprime isotope ratio mass spectrometer connected to a Eurovector Environmental Analyser.

Isotopic ratios $\left({ }^{18} \mathrm{O} /{ }^{16} \mathrm{O}\right.$ and $\left.{ }^{2} \mathrm{H} /{ }^{1} \mathrm{H}\right)$ are expressed in delta units, $\delta^{18} \mathrm{O}$ and $\delta^{2} \mathrm{H}$ (\%o, parts per mille), and defined in relation to the international standard, VSMOW (Vienna Standard Mean Ocean Water). Analytical precision is typically $\pm 0.05 \%$ o for $\delta^{18} \mathrm{O}$ and $\pm 1.0 \%$ ofor $\delta^{2} \mathrm{H}$. Cation analyses were performed by either ICP-MS (Agilent) or ICP-AES (Perkin Elmer Optima 3300RL) for $\mathrm{Ca}, \mathrm{Mg}$ and $\mathrm{Sr}$, and ion chromatography using a Dionex DX500 for Ca, Mg.

\section{RESULTS AND DISCUSSION}

\section{Surface and cave climate}

The three weather stations operated by the Ethiopian Meteorological Service Agency (NMSA) within the study region (Mechara, Gelemso and Bedessa) are all of grade 3, highlighting data that is discontinuous. Data availability was 1968-1976; 1998- (Mechara, $1790 \mathrm{~m}$ a.s.1.), 1969-1991; 2001- (Gelemso, $1800 \mathrm{~m}$ a.s.1.) and 1967-1974; 1980-1991; 1994- (Bedessa, $1820 \mathrm{~m}$ a.s.1.) for monthly mean rainfall and 19731974; 1986-1991 (Gelemso) and 1968-1974; 19811991; 1994 (Bedessa) for monthly mean maximum and minimum temperature.

Mean monthly rainfall and temperature are similar between the stations, demonstrating that the data are largely homogenous despite their discontinuous nature (Figure 5). The three stations show little seasonal variation in solar radiation, and therefore surface temperature, as is expected in low latitude regions. Highest temperatures occur in late spring/ early summer, between the two rainy seasons when cloud cover is relatively low. Mean annual temperature is $19.8^{\circ} \mathrm{C}$ at Gelemso and $19.2^{\circ} \mathrm{C}$ at Bedessa; correlation of monthly mean temperature between the stations is lower than that of rainfall due to the small temperature range $(\mathrm{r}=0.72)$. The strong seasonality and bimodal precipitation is typical of the region. The first rain season, centred on April, is equivalent to the regional 'small rains'; it is highly variable with a 1 standard deviation April mean rainfall range of 60$210 \mathrm{~mm}$ (Baker et al., 2007). The second rain season occurs predominantly in July and August, and is equivalent to the 'big rains' caused by the overhead passage of the ITCZ. This has a 1 standard deviation monthly mean rainfall range of $70-240 \mathrm{~mm}$; again variable but with a higher mean value. Mean monthly precipitation exhibits strong inter-station correlations (Mechara and Bedessa: $r=0.92$; Mechara and Gelemso: $\mathrm{r}=0.93$; Bedessa and Gelemso: $r=0.98$ ). Monthly mean potential evapotranspiration in the region calculated using both Penman and Thornthwaite methods is 65$85 \mathrm{~mm}$ (Wagari Furi, 2005).

Relative humidity measured by handheld Kestrel weather station in the Achere-Aynage, Rukiessa and Weylu caves show a value of $87.5 \pm 11.5 \%(n=24)$, with a similar range of values between the caves (see Table 1).

Cave air temperature was recorded at 30 minutes intervals from October 2005 to March 2007 (number of recordings $=23701$ ) within Asfa Chamber, from June 2006 to September 2007 ( $n=21814)$ within the entrance chamber of the Rukiessa cave, and from October 2005 to June 2006 ( $\mathrm{n}=11088$ ) within the entrance chamber of the Bero cave (Figure 6). Three Tiny tags were placed in the Achere, Aynage and Goda Mea caves in September 2007 and recordings will be recovered in future expeditions. The recovered Tiny tag recordings show that: (i) the temperature in Asfa chamber, Rukiessa cave (Elevation: $1618 \mathrm{~m}$ a.s.1.), which lies about $30 \mathrm{~m}$ beneath the surface remains constant for nearly the whole recording period (close to two years) at $18.93 \pm 0.61^{\circ} \mathrm{C}$; (ii) the temperature record from the Tiny tag placed about $2 \mathrm{~m}$ beneath the Rukiessa cave entrance shows temperatures of $18.03 \pm 1.2^{\circ} \mathrm{C}$; the record also shows greater variation during the months of October to March (values 


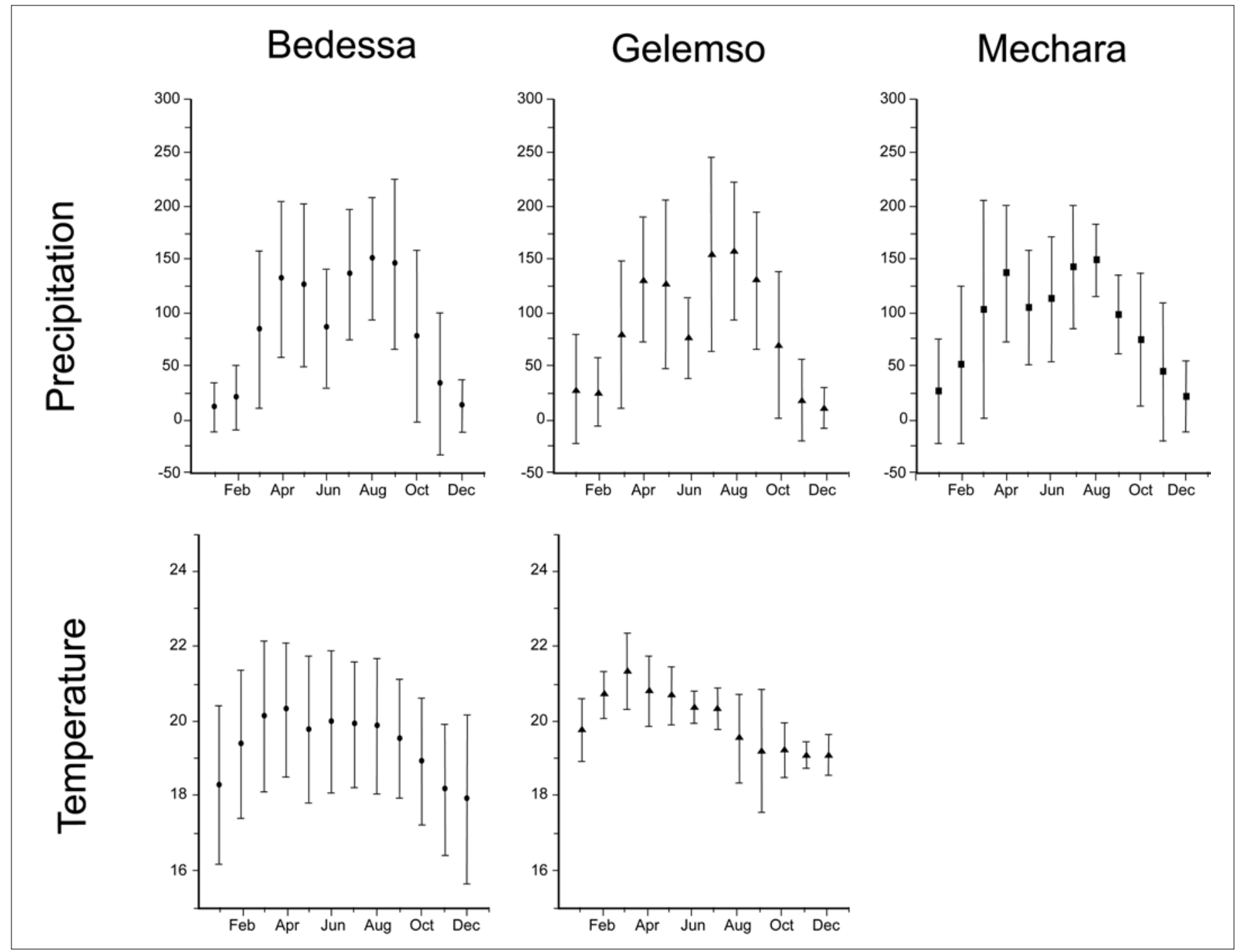

Fig. 5. Mean monthly rainfall $(\mathrm{mm})$ and temperature $\left({ }^{\circ} \mathrm{C}\right)$ series (with standard deviation) from local meteorological stations (Bedessa, Gelemso and Mechara stations).

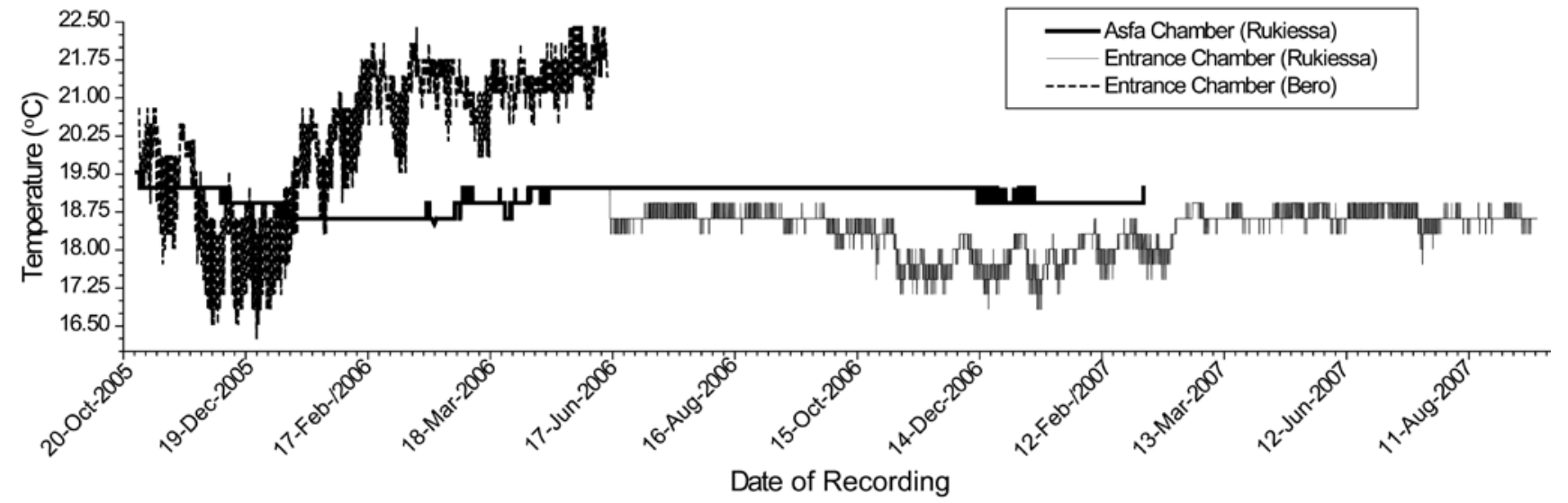

Fig. 6. Tiny Tag temperature records from Rukiessa (Asfa and Entrance chambers) and entrance chamber of Bero cave.

range between $16.8-19.2^{\circ} \mathrm{C}$ ), while it remains nearly constant between April and September-the rainy seasons (values range between $18.3-18.9^{\circ} \mathrm{C}$ ); (iii) the Tiny tag which was placed close to the Bero cave entrance (Elevation: $1363 \mathrm{~m}$ ) records more variable temperatures of $19.47 \pm 2.93^{\circ} \mathrm{C}$. The continuous Tiny tag records confirm that the interior of the caves (e.g., Asfa chamber) show nearly constant temperatures over two years period, while the entrance chambers reflect the surface temperature variations to a certain extent.

\section{Surface and groundwater geochemistry}

The drip rates measured $(n=30)$ in all caves in the region show similar trends where spring (April-May) drips are slightly slower than those measured in September-October after the second rainy season. Drip water geochemistry and cave climate data is presented 


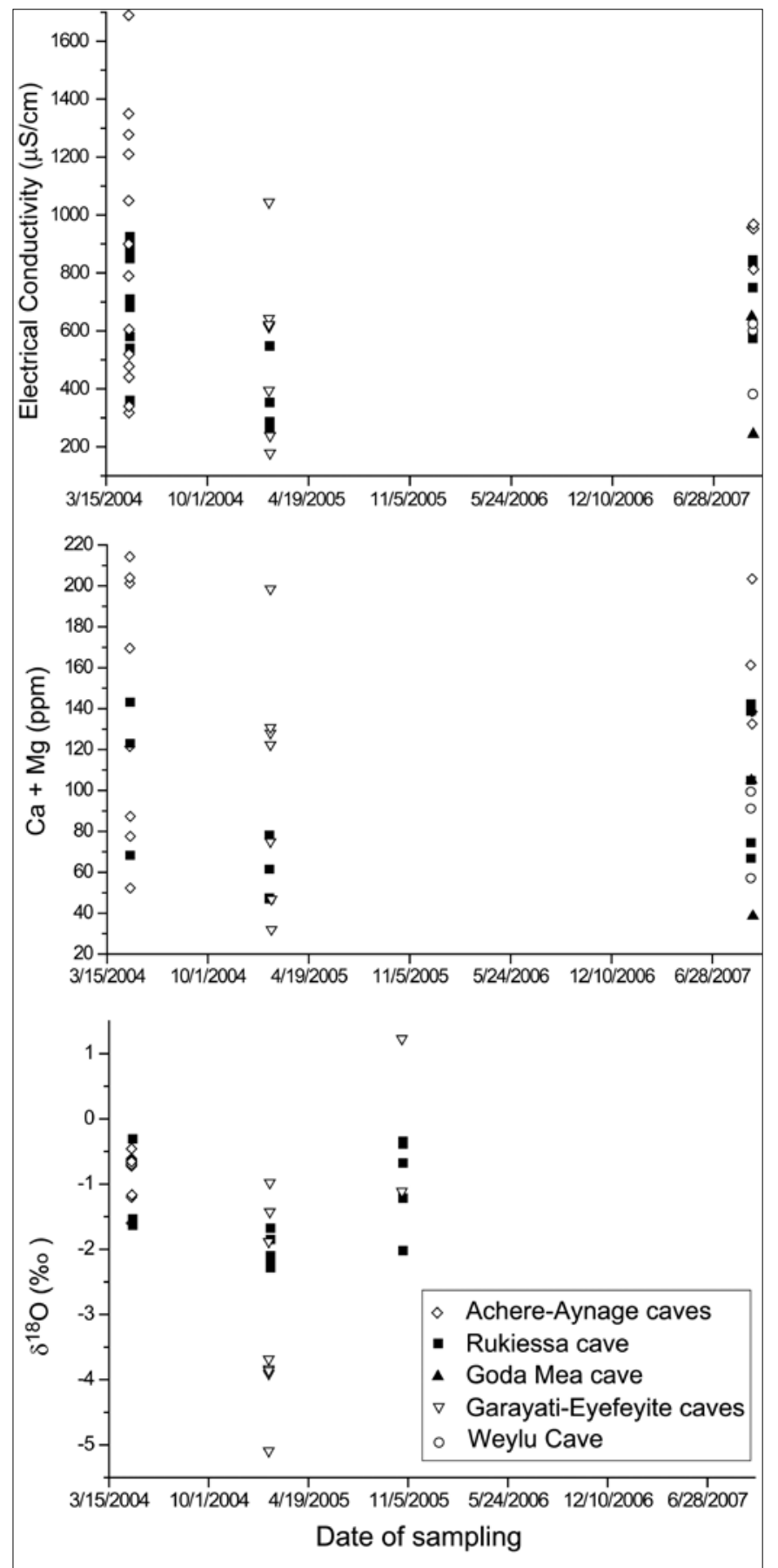

Fig. 7. Variations of electrical conductivity, $\mathrm{Ca}+\mathrm{Mg}$ concentration and $\delta^{18} \mathrm{O}$ of cave drip and pool waters with time.

in Table 1 and Figure 7 . Within cave $\mathrm{CO}_{2}$ concentration measured in Achere-Aynage and Rukiessa caves is $840 \pm 610 \mathrm{ppm}(\mathrm{n}=28)$. However, the concentration in Goda Mea cave was much higher than the region's average when measured in September 2007 (up to $18,000 \mathrm{ppm})$. Drip water electrical conductivity (EC) in the region is $1004 \pm 686 \mu \mathrm{S} / \mathrm{cm}(\mathrm{n}=35)$, with $\mathrm{Ca}$ and $\mathrm{Mg}$ ion concentrations of $105.3 \pm 94.7 \mathrm{ppm}(\mathrm{n}=34)$ and $39.15 \pm 36.85 \mathrm{ppm}(\mathrm{n}=33)$, respectively. Major features identified are: (i) pool waters from Rukiessa, Garayati, Eyefeyite and Goda Mea caves, and spring and river waters show comparable $\mathrm{EC}$ and $\mathrm{Ca}+\mathrm{Mg}$ ion concentrations with those of the drip waters; (ii) the $\mathrm{EC}$ and $\mathrm{Ca}+\mathrm{Mg}$ ion concentration of all samples show a very strong correlation $(\mathrm{r}=0.94)$; (iii) the $\mathrm{EC}$ and $\mathrm{Ca}+\mathrm{Mg}$ ion concentrations exhibit a weak seasonality (see Figure 7); (iv) drip waters from Achere-Aynage cave show higher EC and $\mathrm{Ca}$ ion concentrations and lower $\mathrm{Mg}$ ion concentrations compared to those from other caves; and (v) the Bero cave drip waters have the lowest $\mathrm{Ca}+\mathrm{Mg}$ ion concentrations in the region. These observations indicate that the EC and major ion concentrations of surface and groundwaters in the region are generally similar; however, local lithological variations may control the specific $\mathrm{EC}$ and $\mathrm{Ca}+\mathrm{Mg}$ ion concentrations of waters dripping from them.

Water isotope results for cave drip and pool waters, springs and river waters in the region are presented in Table 1 and Figures 7 and 8. Modern drip water isotope data falls on both the global and Addis Ababa meteoric water lines. To date, we do not have enough rainfall data from the study region to produce a local meteoric water line; however, presuming that this is similar to that of Addis Ababa then it would confirm the dominance of equilibrium fractionation processes rather than evaporation. Cave drip waters show $\delta^{18} \mathrm{O}$ and $\delta^{2} \mathrm{H}$ values ranging between -2.3 to $-0.3 \%$ o $(\mathrm{n}=17)$ and -2.3 to $+13.1 \%$ o $(\mathrm{n}=16)$, respectively, and cluster around the weighted annual mean value $\left(\delta^{18} \mathrm{O}\right.$ $=-0.8 \%$; $\delta^{2} \mathrm{H}=+4 \%$ o). On the other hand, cave pool waters exhibit greatest isotope variability with $\delta^{18} \mathrm{O}$ and $\delta^{2} \mathrm{H}$ values ranging between -5.1 and $+1.2 \%$ $(\mathrm{n}=17)$ and -27.1 to $+19 \%$ o $(\mathrm{n}=18)$, respectively. Springs and river waters show isotope values that fall within the range of those of cave drip waters. Seasonal variations of up to $2 \%$ in $\delta^{18} \mathrm{O}$ have been observed in one particular drip in the Rukiessa cave (Mercury chamber drip) with samples collected after spring rains isotopically heavier than those collected after the summer rains, reflecting the composition of the spring rainfall and suggesting at this drip site a rapid flow component. This trend is repeated in the region where the average $\delta^{18} \mathrm{O}$ value of drips collected in October and February is lighter by $\sim 1.5 \%$ o than

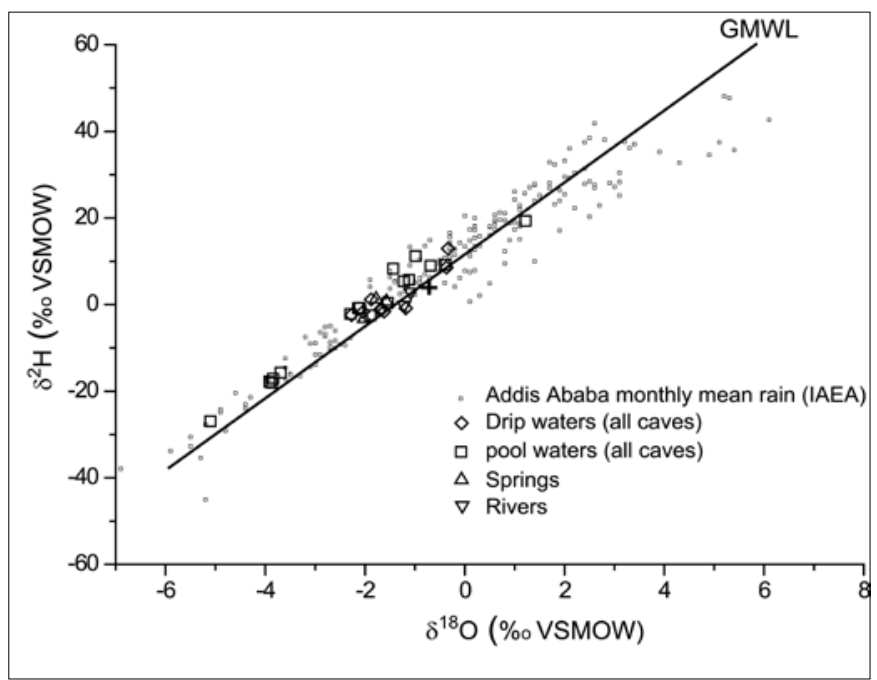

Fig. 8. $\delta^{18} \mathrm{O}$ and $\delta^{2} \mathrm{H}$ for cave drip waters, pools, springs, and river waters, along with the monthly mean isotopic composition of rainfall from Addis Ababa. The cross shows annual weighted mean isotopic composition of rainfall. The evaporative trend in the Addis Ababa regional MWL is generally attributed to the 'Pseudo altitude effect' of the Ethiopian rift margin, which is located on the leeward side of the Atlantic and Indian Oceans moisture sources (Kebede et al., 2008). 
those collected in April-May. Using the observed drip water $\delta^{18} \mathrm{O}$ and cave air temperature, and equations of O’Neil et al. (1969), Hays \& Grossman (1991) and Leng \& Marshall (2004) expression of Kim \& O'Neil (1997) equation, we predicted equilibrium calcite $\delta^{18} \mathrm{O}$ to be $-1.2 \%$ o to $-3.3 \%$ o (Baker et al., 2007).

\section{STUDIED SPELEOTHEMS AND PALAEOCLIMATE RECORDS}

High resolution, multi-proxy palaeoclimate records of the Holocene have been recovered from four stalagmites removed from Rukiessa (Asfa-3 and Merc-1), Achere (Ach-1) and Bero (Bero-1) caves (Asrat et al., 2007, Blyth et al., 2007, Baker et al., 2007, 2008). More stalagmites removed from these caves and others from the Aynage, Goda Mea and Weylu caves are under investigation for their palaeoclimate records. The stalagmites from the region have the following common features:

All studied stalagmites have continuous visible laminae with alternating White Porous Laminae (WPL) and Dark Compact Laminae (DCL) as defined by Genty \& Quinif (1996) and Genty et al. (1997); thick White Porous Calcite (WPC) and Dark Compact Calcite (DCC) layers represent these laminae, respectively. The colourless calcite deposition, in contrast to periods of dark calcite that are brown in colour in hand specimen, represent the absence of higher concentrations of humic substances (Lauritzen et al., 1986; White \& Brennan, 1989) that would be observed in wetter periods. Prominent
WPL in Asfa-3 and Merc-1 stalagmites from the Rukeissa cave recorded periods of known drought in the region in 1905-30 and 1984 AD (Baker et al., 2007). Moreover, all studied modern stalagmites from separate caves in the region depict similar laminae textures and stratigraphy in hand sections with alternating growth phases dominated by light and dark coloured calcite at the centimetre-scale, as well as similar alternations at the sub millimetre scale to form regular laminae (examples are given in Figure 9A and B). In thin section, most stalagmites show laminae that are defined by zones with multiple thin laminae represented by impurities, which drape crystallite surfaces that occasionally show some dissolution features (examples are given in Figure 9C and D, representing Asfa-3 and Merc-1, respectively). Baker et al. (2007) considered these surfaces to occur annually during the winter dry season due to drip cessation, or very slow drip rates, and interpreted the groups of opaque laminae to be infiltration laminae characterized by the input of detrital and colloidal material during periods of infiltration (Borsato et al., 2007), and the impurity-bearing laminae as representing seasonally high flows.

The stalagmites are generally fast growing. Laminae in the Holocene stalagmites (Ach-1 and Bero-1) have an average thickness of $\sim 0.5 \mathrm{~mm}$, and laminae thickness in the modern stalagmites (Asfa-3 and Merc-1) varies between 0.2 and $0.4 \mathrm{~mm}$, with some thicker laminae observed in periods of porous calcite deposition. This observation from
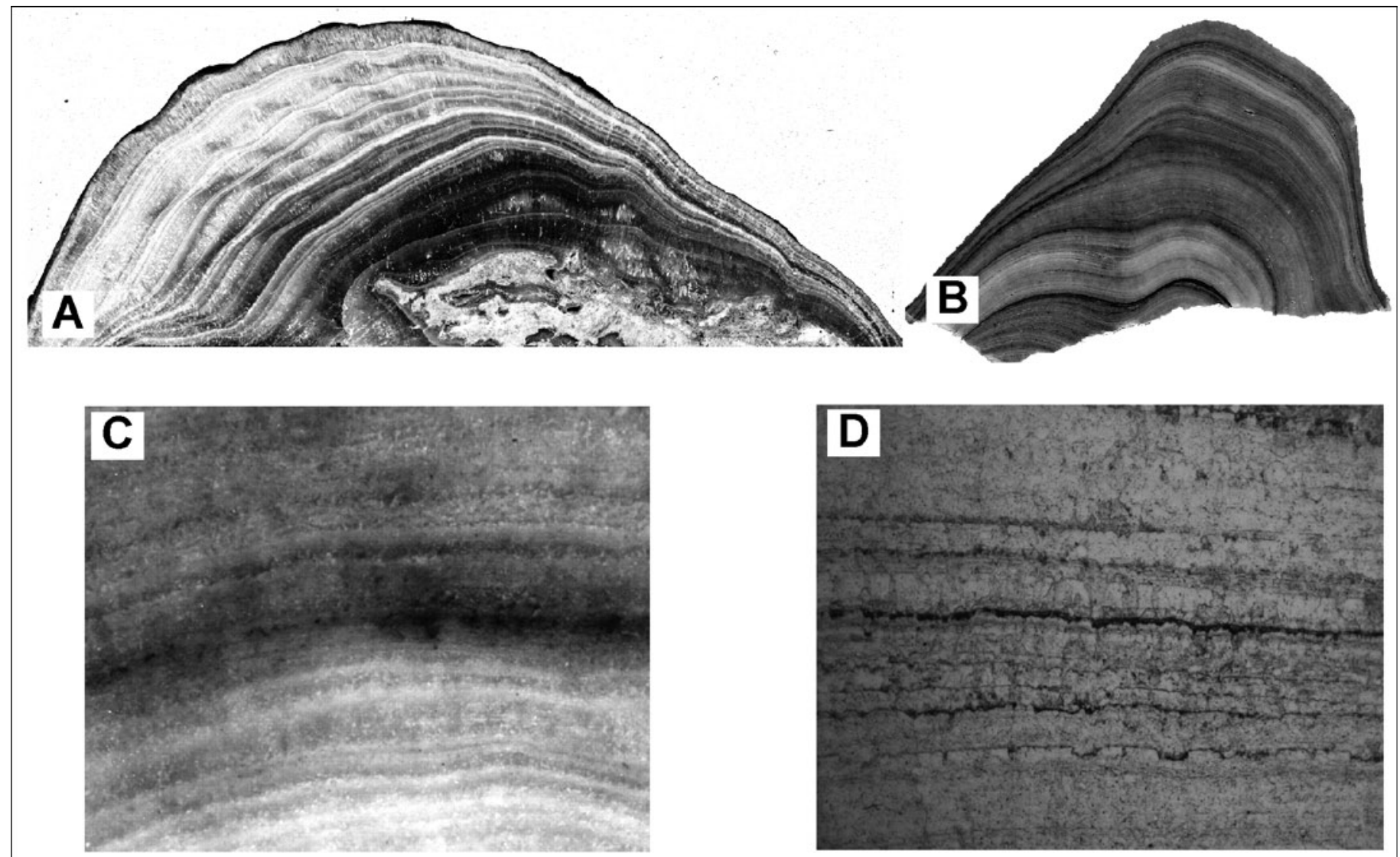

Fig. 9. Hand sections ( $A$ and $B$ ) and thin sections ( $C$ and $D$ ) of modern stalagmites (deposited during the last century) from two separate caves showing striking similarity in lamina texture and stratigraphy: (A) GM-11 from Goda Mea cave and (B) Asfa-3 from Rukiessa cave. Microscopic section of Asfa-3 (C) and thin section of Merc-1 (D) show groups of opaque laminae interpreted to be infiltration laminae. 
the modern stalagmites agrees with those expected for annual laminae which are predicted to grow at the rate of $0.2-0.3 \mathrm{~mm} / \mathrm{yr}$, prediction based on the temperature of the cave, atmospheric $\mathrm{PCO}_{2}$ and calcium and magnesium concentrations of the drip waters (Dreybrodt, 1981; Baker et al., 1998).

Laminae counting controlled by TIMS U-Th dating confirmed the annual nature of the laminae (Asrat et al., 2007). Moreover, all stalagmites show continuous and regular laminae sequences with no periods of indistinct or discontinuous laminae, therefore they are indicative of annual climate forcing (Tan et al., 2006). These sequences are typically 100-1000 years long, interrupted by growth hiatuses.

Studied modern stalagmites generally show disequilibrium deposition. Based on our modern drip water data (Table 1 and Figure 8), we have shown that the stalagmite samples should have $\delta^{18} \mathrm{O}$ variations within the range $-1.2 \%$ and $-3.3 \%$, if they are in isotopic equilibrium, and which should primarily reflect variations in rainfall. However, the $\delta^{18} \mathrm{O}$ profiles for Asfa-3, Merc-1, and Bero-1 (Baker et al., 2007, 2008) show values that are either representing the highest predicted values (in case of Asfa-3 and Merc-1) or heavier than those predicted from modern drip waters (in case of the modern deposit of Bero-1). Moreover, modern straw stalactites have $\delta^{18} \mathrm{O}=-0.59 \pm 0.13(\mathrm{n}=6)$, suggesting that deposition is heavier than that predicted from waters in equilibrium.

Studied stalagmites are strongly fluorescent and also have high enough concentrations of lipids for paleoenvironmental reconstruction (Blyth et al., 2007). It is believed that warm and moist climate make the region ideal for efficient soil microbial activity and the rapid production and breakdown of soil organic matter. We have found out that high fluorescence index peaks in a mid Holocene stalagmite (Ach-1) correlate with periods of DCC, indicating deposition of high molecular weight or more aromatic organic matter, substances which are relatively hydrophobic and indicative of the presence of humic substances (Asrat et al., 2007). Blyth et al., (2007) investigated Asfa-3 stalagmite for lipid biomarkers and found out that plant-derived lipids ( $n$-alkanes) preserved in this stalagmite show clear changes in composition over time, relating to known land-use changes in the area, particularly the expansion of agriculture in the 1930s and the change in crop systems from cereals to khat (Catha edulis) and coffee (Caffea sp.) over the last twenty years.

Analyses of palaeoclimate records from the studied stalagmites confirmed that the considered proxies (growth rate, stalagmite morphology, oxygen isotope, fluorescence index) respond in a complex manner to linear climate forcing/ change. For instance, Ach-1 stalagmite, which shows decadal scale (18-21 yr) growth rate and $\delta^{18} \mathrm{O}$ variability has three growth phases which respond to changes in the hydrological flow routes of dripwater to the stalagmite over time (Asrat et al., 2007). Similarly, some modern stalagmites respond more to high frequency ('event') climate (Merc-1) and others to low frequency ('storage') climate (Asfa-3), due to differences in their relative contributions to the stalagmite drip waters (Baker et al., 2007). Different parameters also respond to different seasons, and in some cases the same parameter responds to different months or seasons via different forcing mechanisms (e.g., rainfall seasonality or amount, or non-equilibrium factors). Our analysis of the stalagmites strongly suggested that multi-parameter, multi-proxy approach is the best way to characterize climate (especially rainfall) variability in the region.

Episodic growth with significant number of nongrowth periods (hiatus) seems to be common in both the Holocene and modern stalagmites. Considering the fact that the Mechara caves are located close to the Main Ethiopian Rift and is a seismically active area, some of the non-growth periods might be initiated by major earthquake events, which created instability in drip water supply. For instance, major breaks in 1906 on the Rukiessa stalagmites and in 1960-61 on the Bero stalagmite correspond to recorded earthquakes (magnitude > 6) whose epicentres were located close to the Mechara area (Gouin, 1979; Ayele \& Kulhánek, 2000).

\section{CONCLUSIONS}

Monitoring of the Mechara caves over a period of 5 years set a modern baseline for understanding past processes. Cave climate (temperature and humidity) is nearly constant in all caves and generally reflects surface climate; groundwater and surface water geochemistry shows similarity across the region, except slight modification by local lithological variations; modern drip water isotope data falls on both the global and local meteoric water lines, demonstrating the dominance of equilibrium fractionation processes rather than evaporation. The modern baseline data made interpretation of palaeoclimate records contained in Holocene and modern speleothems collected from the monitored caves easier. All studied Holocene and modern speleothems from these caves gave highresolution climate records, implying that the Mechara caves provided a suitable setting for the deposition of annually laminated speleothems that could record surface climate variability. Moreover, the location of the caves in the Southeastern Ethiopian plateau, a region where rainfall is sensitive to both the strength of the intertropical convergence zone as well as Indian Monsoon variability, allows the deposition of annually laminated speleothems, because of the strong seasonality of rainfall. Our investigation confirmed that speleothems from the Mechara caves have the potential to provide long, high temporal resolution climate (mostly rainfall) records. Characterizing rainfall variability (using such archives as speleothems) in a region where instrumental records are very short and unreliable, while the majority of its population strongly depends on a rain-fed agriculture for survival is very crucial. 


\section{ACKNOWLEDGEMENTS}

Research was supported by a Leverhulme and NERC grants to $A B$, a START grant to AA, a SIDASAREC-AAU grant to AA and MU, and a Royal Society International Exchange Grant to AA and AB. We thank Hailu Dibabe and Adem for field support, Hilary Sloane and Ian Boomer for the stable isotope analyses, Steve Noble and Louise Thomas for the U-Th analyses, and Peter Wynn and Lisa Fuller for cation analyses.

\section{REFERENCES}

Asrat A. 2002 - The rock-hewn churches of central and eastern Tigrai: a geological perspective. Geoarchaeology, 17: 649-663.

Asrat A., Baker A., Umer M.M., Leng M.J., Van Calsteren P. \& Smith C., 2007 - A high-resolution multi-proxy stalagmite record from Mechara, Southeastern Ethiopia: palaeohydrological implications for speleothem palaeoclimate reconstruction. Journal of Quaternary Science, 22: 53-63.

Assefa G., 1988 - Potential hydrocarbon generating rock units within the Phanerozoic sequence of the Ogaden Basin, Ethiopia: a preliminary assessment using the Lopatin model. Journal of Petroleum Geology, 11: 461-472.

Ayele A. \& Kulhánek O., 2000 - Reassessment of source parameters for the major earthquakes in the East African rift from historical seismograms and bulletins. Annali di Geofisica, 43: 81-94.

Baker A., Genty D., Dreybrodt W., Grapes J. \& Mickler NJ., 1998 - Testing theoretically predicted stalagmite growth rate with recent annually laminated stalagmites: implications for past stalagmite deposition. Geochimica et Cosmochimica Acta, 62: 393-404.

Baker A., Asrat A. \& Mohammed M., 2005 - Expedition Report to the Mechara caves, Southeastern Ethiopia. Speleology, 5: 8-20.

Baker A., Asrat A., Fairchild I.J., Leng M.J., Wynn P.M., Bryant C., Genty D. \& Umer M., 2007 - Analysis of the climate signal contained within $\delta^{18} \mathrm{O}$ and growth rate parameters in two Ethiopian stalagmites. Geochimica et Cosmochimica Acta, 71: 2975-2988.

Baker A., Asrat A., Fairchild I.J., Leng M.J., Thomas L. \& Van Calsteren P., 2008 - A Holocene, High resolution, seasonal rainfall reconstruction from Ethiopia, KR5 Conference, 2-5 June 2008, China.

Blyth A.J., Asrat A., Baker A., Gulliver P., Leng M.J. \& Genty D., 2007 - A new approach to detecting vegetation and land use change using high-resolution lipid biomarker records in stalagmites. Quaternary Research, 68: 314-324.

Borsato A., Frisia S., Fairchild I.J., Somogyi A. \& Susini J., 2007 - Trace element distribution in annual stalagmite laminae mapped by micrometer-resolution $X$-ray fluorescence: implications for incorporation of environmentally significant species. Geochimica et Cosmochimica Acta, 71: 1494-1512.

Bosellini A., Russo A., Fantozzi P.L., Assefa G. \& Tadesse S., 1997 - The Mesozoic succession of the Mekele Outlier (Tigrai Province,Ethiopia). Memorie di Scienze Geologiche, 49: 95-116.
Brown L., Gunn J., Walker C. \& Williams O., 1998 - Cave Ethiopia '95 and '96 Expedition Report. University of Huddersfield, UK, 28p.

Bruggeman H.Y.W., 1986 - Provisional Soil Association Map of Ethiopia, 1:2,000,000. Ministry of Agriculture, Addis Ababa, Ethiopia.

Dreybrodt W., 1981 - The kinetics of calcite deposition from thin films of natural calcareous solutions and the growth of speleothems: revisited. Chemical Geology, 32: 237-245.

Genty D. \& Quinif Y., 1996 - Annually laminated sequences in the internal structure of some Belgian stalagmite-importance for palaeoclimatology. Journal of Sedimentary Research, 66: 275-288.

Genty D., Baker A. \& Barnes W.L., 1997 - Comparison of annual luminescent and visible laminae in stalagmites. Comptes Rendus Academie Sciences Paris, Serie II, 325: 193-200.

Gouin P., 1979 - Earthquake History of Ethiopia and the Horn of Africa. International Development Research Center, Ottawa, Canada, 259p.

Griffiths J.F., 1972 - Ethiopian Highlands. In: Landsberg H.E. (Ed.) - World Survey of Climatology, 10: 369-381.

Gunn J. \& Brown L. 1998. Speleogenesis in the Mechara area, Western Harrar, Ethiopia. Proceedings of the $2^{\text {nd }}$ International Symposium on Karst Water Resources, Iran, 224-231.

Hays P.D. \& Grossman E.L., 1991 - Oxygen isotopes in meteoric calcite cements as indicators of continental paleoclimate. Geology, 19: 441-444.

Kebede S., Travi Y., Asrat A., Tamiru A. Ayenew, T. \& Tessema, Z.,2008 - Groundwater origin and flow along selected transects in East African rift volcanic aquifers. Hydrogeology Journal, 16: 55-73.

Kim S.T. \& O'Neil J.R., 1997 - Equilibrium and nonequilibrium oxygen isotope effects in synthetic carbonates. Geochimica et Cosmochimica Acta, 61: 3461-3475.

Lauritzen S.E., Ford D.C. \& Schwarz H.P., 1986 - Humic substances in a speleothem matrix. Proceedings of the $9^{\text {th }}$ International Congres of Speleology, 77-79.

Leng M.J. \& Marshall J.D., 2004 - Palaeoclimate interpretation of stable isotope data from lake sediment archives. Quaternary Science Reviews, 23: 811-831.

Machado M.J. Perez-Gonzalez A. \& Benito G., 1998 Paleoenvironmental changes during the last $4000 \mathrm{yr}$ in the Tigray. Northern Ethiopia. Quaternary Research, 49: 312321.

Nicholson S.E., 2000 - The nature of rainfall variability over Africa on time scales of decades to millennia. Global Planetary Change, 26: 137-158.

O’Neill J.R., Clayton R.N. \& Mayeda T.K., 1969 - Oxygen isotope fractionation in divalent metal carbonates. Journal of Chemical Physics, 51: 5547-5558.

Ruggieri R., 2006 - Dentro gli altopiani della Rift Valley, I risultati di due spedizioni in cerca di nuove regioni carsiche dell'Etiopia. Speleologia, 54: 56-64.

Seleshi Y. \& Zanke U., 2004 - Recent changes in rainfall and rainy days in Ethiopia. International Journal of Climatology, 24: 973-983.

Tan M., Baker A., Genty D., Smith C., Esper J. \& Cai B., 2006 - Applications of stalagmite laminae to paleoclimate reconstructions: comparison with dendrochronology/ climatology. Quaternary Science Reviews, 25: 2103-2117. 
Wagari Furi 2005 - Groundwater productivity and the hydrology of dry lakes basin in North-Central sector of East Harrarghe Zone. Unpubl. MSc Thesis, Addis Ababa University, 89p.
White W.B. \& Brennan E.S., 1989 - Luminescence of speleothems due to fulvic acid and other activators. Proceedings of the $10^{\text {th }}$ International Congress of Speleology, 212-214. 